\title{
心肺疾患を伴った下顎苗肉癌患者の治療経験
}

\author{
岡政 文・森下徹也・吉村安 郎
}

\section{A case of gingival cancer in a patient with heart and lung complications}

\author{
Masafumi Ока - Tetuya Morishita - Yasuro Yoshimura
}

\begin{abstract}
As the aged population increases general complications of patients with head and neck cancer have increased. Then previous and present general illnesses of the patient should be carefully noted and decisions on his best therapies should be done.

This paper describes a case of gingival cancer with heart and lung complications, and postoperative transient myocardial ischemia from the aspect of patient management.

The patient was a 72-year-old male with gingival cancer of the mandible (T1N0M0) who suffered from pulmonary fibrosis, secondary pneumonia and a complete left bundle branch block (LBBB). The patient was treated with radical surgery under general anesthesia (GOF) and tolerated the procedure well, and subsequently was sent to the ICU, though he was in satisfactory condition.

He did not complain of dyspnea and chest pain ST segment depression and negative $\mathrm{T}$ wave were caused by nasopharyngeal pain of the feeding tube, by coughing, and by changes of body positions in the early postoperative period. Laboratory examinations, such as CK and LDH isoenzymes showed normal valves. On the eleventh day negative $T$ wave returned to normal. These findings suggested transient myocardial ischemia. Ambulatory electrocardiographic and echocardiographic observations revealed no underlying cause of transient myocardial ischemia and LBBB.

Further severe pulmonary complication after surgery had been prevented by urged expectoration, sustained maximum inspiration, subseqent oxygen therapy, control of pain and medicaticn of antibiotics.
\end{abstract}

Key words: transient myocardial ischemia (一過性心筋虚血), gingival cancer of mandible (下顎㳡 肉癌), general complications (全身的合併症)

緒言

人口の高踚化に伴い，心肺疾患は増加の傾向にある.

島根医科大学医学部蔽科口腔外科学諈座 (主任：吉村安郎教授)

Department of Oral and Maxillofacial Surgery, Simane Medical University (Chief: Prof. Yasuro Yoshimura)

受付日：平成元年 3 月 15 日
頭頸部悪性腫瘍患者においても種々の全身的合併症に羅 患している場合が多く, 治療や患者管理の点で注意深い 配虑を要するとともに関連領域の専門医との連携が重要 となっている。

今回, 肺疾患としては肺線維症と肺二次感染を発症 し，心疾患としては完全左脚ブロックを伴った下買歯肉 癌患者の外科療法を施行する機会を得た。本症例は口腔 外科に拈ける全身管理上の問題点を含んでいると考兄ら れたのでその概要を報告し，その問題点を検討した。 


\section{症}

\section{例}

患 者: 72歳 男性.

初 診: 昭和 62 年 3 月回.

主 訴: 左側下靧歯肉部の腫瘤.

家族歴：特記事項なし.

既往歴：昭和 43 年飞肺結核，昭和 62 年 2 月に肺線維 症, 肺二次感染, 完全左脚ブロックと猃断され, 昭和62 年 3 月まで某病院内科にて入院加療を受けていた。

現病歴: 昭和 62 年 3 月入院中江左側下買大日歯部齿肉 の自発痛招よび接触時痛を自覚し同院の歯科を受揨し た. 生検したところ扁平上皮癌であったため当科に紹介 された. 内科的には呼吸障害は比較的改善したとのこと で転科となった。

\section{現 症}

全身所見.身長 $162 \mathrm{~cm}$, 体重 $42 \mathrm{~kg}$ で体格はややひ 弱であったが栄養状態は良好であった．顔面はやや負血 様を呈していたが浮聥, キアノーゼなどは諗めなかっ た。呼吸状態は正常で胸郭の変形や心尖部拍動は認めな かった。しかし、ときどき著しい湿性咳濑, 喘息栚発作が あり，労作性呼吸困難を認め，呼吸困難の分類 (HughJones の分類) では第 3 度と考えられた。さらに，両肺 野に侩㰮音様ラ音 (ベルクロ・ラ音) と左側第 $4 \sim 5$ 助 間で収緶期雑音を聴取した。

局所所見：左側下買後田歯部から上行枝部にかけて $18 \times 11 \mathrm{~mm}$ のカリフラワー状の腫瘤があり, 辺縁部に 軽度の硬結を認めた（写直1）。X線的には罰骨への浸
潤はなく，また所属りンパ節への転移は認めなかった。

臨床険查：軽度の筫血と活性部分トロンボブラスチン 時間の延長を認め, ZTT 19.4 K.U, TTT 15.7 K.U と 高值であったが，その他の血液生化学検査，尿検査は正 常範囲であった，堅機能検査ではクレアチニンークリフ ランスは正常であったが，PSP の排泄障害があり尿細 管機能障害が示唆された。動脈血ガス分析では $\mathrm{PaO}_{2}$ は $68 \mathrm{mmHg}$ と低值を示したが，酸素含量および酸素餙和 度は正常範囲であった．眠機能では中等度の拘束性換気 障害を認めた。最大中間呼気速度は正常であった（表 1).

心電図所見：水平位心を示し，PR 間隔の延長，完全 左脚ブロック，上室珄期外収縮が認められた（図 $1 \mathbf{A}$ ）。

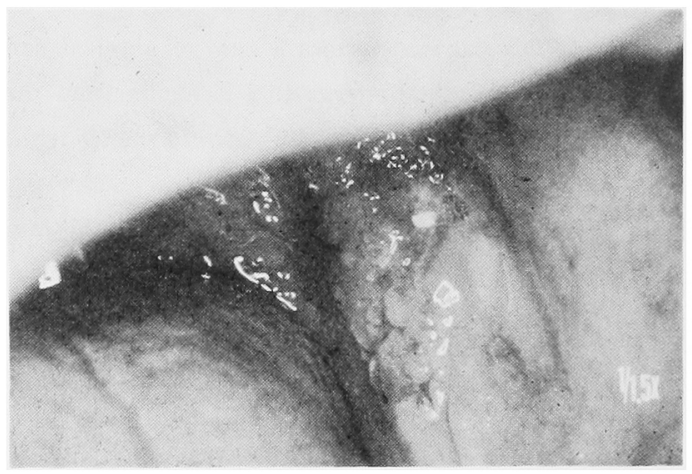

写真 1 初診時口腔内写真

左側下影後田齿部から上行枝部にかけて盾瘤をみる

表 1 臨床挨查成篊

\begin{tabular}{|c|c|c|c|c|c|}
\hline \multicolumn{2}{|c|}{ 血液一般検查 } & Ccr 24時間値 & $109 \mathrm{l} / \mathrm{B}$ & $\mathrm{ZTT}$ & 19. 4 K.U \\
\hline $\mathrm{RBC}$ & $373 \times 10^{4} / \mu l$ & 肺機能㭘査 & & TTT & $15.7 \mathrm{~K} . \mathrm{U}$ \\
\hline WBC & $5,700 / \mu l$ & FVC & $2,150 \mathrm{ml}$ & T. $\mathrm{CHO}$ & $182 \mathrm{mg} / \mathrm{d} l$ \\
\hline $\mathrm{Hgb}$ & $11.9 \mathrm{~g} / \mathrm{d} l$ & $\%$ FEV1. 0 & $92 \%$ & BUN & $16 \mathrm{mg} / \mathrm{d} l$ \\
\hline Hct & $35.0 \%$ & $\% \mathrm{VC}$ & $67 \%$ & Crea & $1.0 \mathrm{mg} / \mathrm{d} l$ \\
\hline PLT & $208 \times 10^{3} / \mu l$ & FEF 25-75 & 3. $40 \mathrm{l} /$ 秒 & $\mathrm{Na}$ & $143 \mathrm{mEq} / \mathrm{l}$ \\
\hline 止血检查 & & 血液生化学㭘査 & & K & $4.7 \mathrm{mEq} / l$ \\
\hline カルシ & 固昿間 & T.P & $7.8 \mathrm{~g} / \mathrm{d} l$ & $\mathrm{Cl}$ & $104 \mathrm{mEq} / \mathrm{l}$ \\
\hline & 16.5 秒 & ALB & $4.0 \mathrm{~g} / \mathrm{d} l$ & $\mathrm{Ca}$ & $8.5 \mathrm{mEq} / \mathrm{l}$ \\
\hline PT & 12. 2 秒 & $\mathrm{A} / \mathrm{G}$ & 1.1 & FBS & $83 \mathrm{mg} / \mathrm{d} l$ \\
\hline APTT & 42.2 秒 & T. Bil & $0.3 \mathrm{mg} / \mathrm{d} l$ & 動脈血ガス分析 & \\
\hline$フ_{1} フ$ & 定量 & GOT & $25 \mathrm{IU} / l$ & $\mathrm{pH}$ & 7.38 \\
\hline & $360 \mathrm{mg} / \mathrm{d} l$ & GPT & $17 \mathrm{IU} / l$ & $\mathrm{PaO}_{2}$ & $68 \mathrm{mmHg}$ \\
\hline PSP & & $\mathrm{LDH}$ & $386 \mathrm{IU} / l$ & $\mathrm{PaCO}_{2}$ & $41 \mathrm{mmHg}$ \\
\hline 15 & $3.0 \%$ & ALP & $50 \mathrm{IU} / l$ & $\mathrm{HCO}_{3}^{-}$ & $25 \mathrm{mmol} / l$ \\
\hline $30^{\prime}$ & $31.9 \%$ & $\mathrm{CK}$ & $77 \mathrm{IU} / l$ & $\mathrm{BE}$ & $0 \mathrm{mmol} / \mathrm{l}$ \\
\hline $60^{\prime}$ & $6.1 \%$ & ChE & $1,182 \mathrm{IU} / l$ & $\mathrm{O}_{2} \mathrm{CT}$ & $20 \mathrm{~m} l / \mathrm{d} l$ \\
\hline $90^{\prime}$ & $20.0 \%$ & Amy & $394 \mathrm{IU} / l$ & $\% \mathrm{O}_{2} \mathrm{SaT}$ & $93 \%$ \\
\hline
\end{tabular}


A

P)

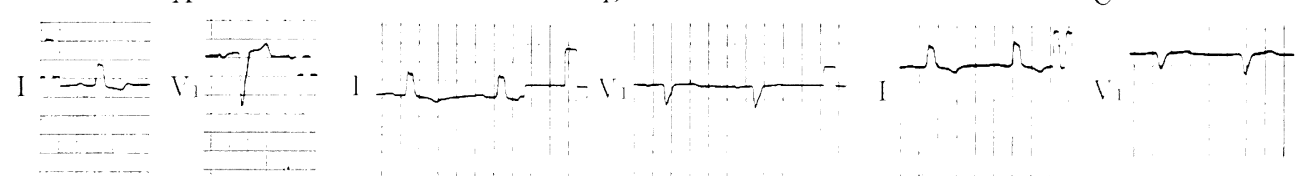

$I I+\overbrace{2}$

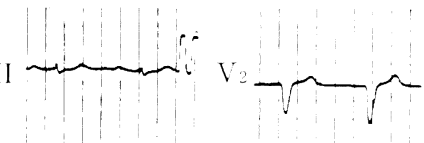

$111 \ldots \sim \sim \sim c$
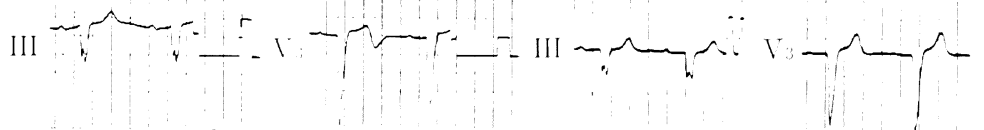

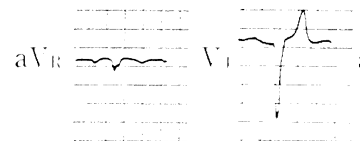
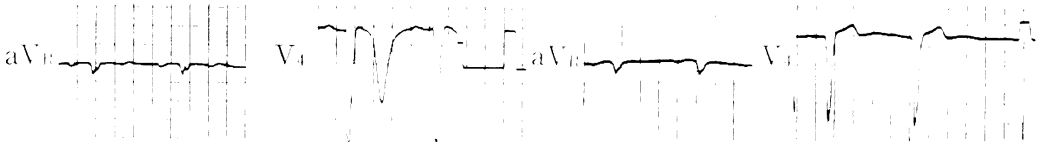

$a V_{1}$
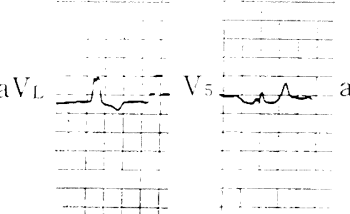

ali

$\mathrm{aV}$
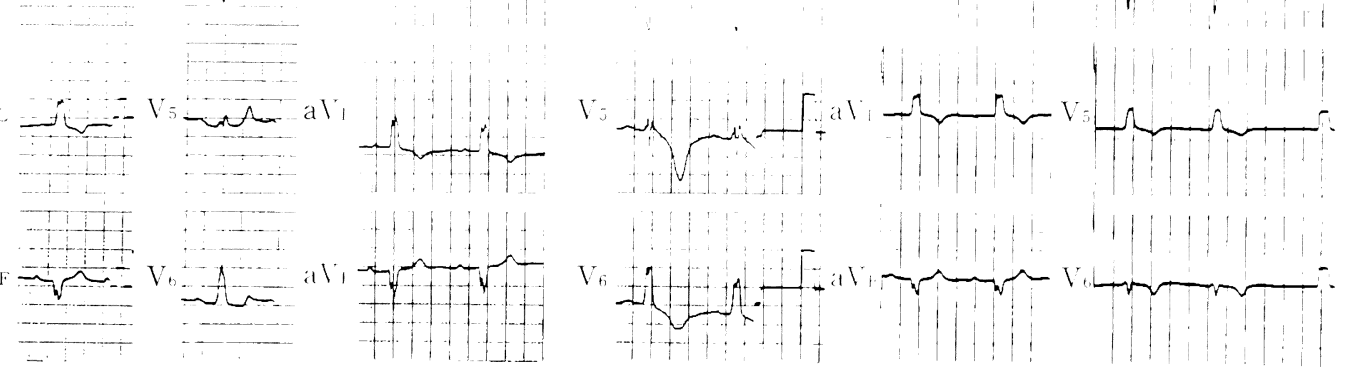

図 1 心電図の変化
$\mathrm{A}$ ：入院時, 完全左脚ブロックを認める
$\mathrm{B}$ ：脯後 1 日目で $\mathrm{V}_{2}, \mathrm{~V}_{3}, \mathrm{~V}_{4}, \mathrm{~V}_{5}$ で陰性 $\mathrm{T}$ 波を認める
$\mathrm{C} ：$ 㭪後11日目の心電図

胸部 $\mathbf{X}$ 線所見：両肺野全体にびま几性の線維性変化が みられ，一部に蜂巣状陰影を認めた。心肺比は約 $50 \%$ で あった（写真 2).

臨床診断：左側下㴿雨肉癌 (T1 N0 M0)

処置および経過 : 当科入院後ただちに内科的精查を行 い, 咳嗽, 喘息様発作に対して気管支払張剂, 鎮咳去痰 剤などを投薬した。症状の改善が認められた後, 麻酔医 との術前検討では手術危険度は 3 度で短時間の体表の手 術であれば可能との結論が得られた。また術後の肺合併 症の予防のためトリフローII（写真了）による呼吸練習 を術前より開始した。

麻酔および手術経過：前投薬として硫酸アトロピン $0.4 \mathrm{mg}$, 塩酸七ドロキシジン $50 \mathrm{mg}$ を執刀予定 1 時間 前に筋注した。手術場入室時の血圧は $120 / 84 \mathrm{mmHg}$, 脈拍 $70 /$ 分で心電図上特に变化は認めなかった。 チアミ ラール $75 \mathrm{mg}$ を静脈内投与し，経鼻插管で，笑気一酸 素一ハロセンにて維持した。

手術はNd-YAG レーザーも使用し，下顎骨を一部含 めた腫煌切除を行った．術中拡張期血圧のやや低下と心
拍数の軽度增加を認めたが心電図モ二ター上に異常はな かった。術後は呼吸管理および肺合併症の予防のため集 中治療部にて管理した。

術後経過：咳嗽と気道内分泌は著明であったが重篤な 肺合併症もなく, 胸部痛や胸部不快感なども認めなかっ た。しかし，抬張期血圧の軽度低下，ときどき単発性に 心室性期外収縮と A-V ブロックが出現した。拔管後 3 時間経過した頃, 激しい咳濑時に一過性の著明な ST 低 下が出現した。 その後, 仰臥位から側臥位への体位変換 時, 咳濑時, 患部痛, 胃管による鼻咽頭部痛などで陰性 T波が出現した。

図 $1 \mathbf{B}$ は術後 1 日目の安静時の心電図であるが $V_{2}$, $\mathrm{V}_{3}, \mathrm{~V}_{4}, \mathrm{~V}_{5}$ で著明な陰性 $\mathrm{T}$ 波が認められた。 CK, GOT, $\mathrm{LDH}$ の軽度の上昇を認めたが, 術後 4 日目の CK お上 び LDH アイソザイム分析ではともに正常範囲であっ た。術後11日目の心電図にて陰転T波は正常化した（図 $1 \mathbf{C}$ )。 その後, 長時間連続記録心電図（ホルター心電 因）を装着したが虚血性変化や上室性期外收縮は認めら れず，心ェコー図による精査でも左室肥大および抁張は 


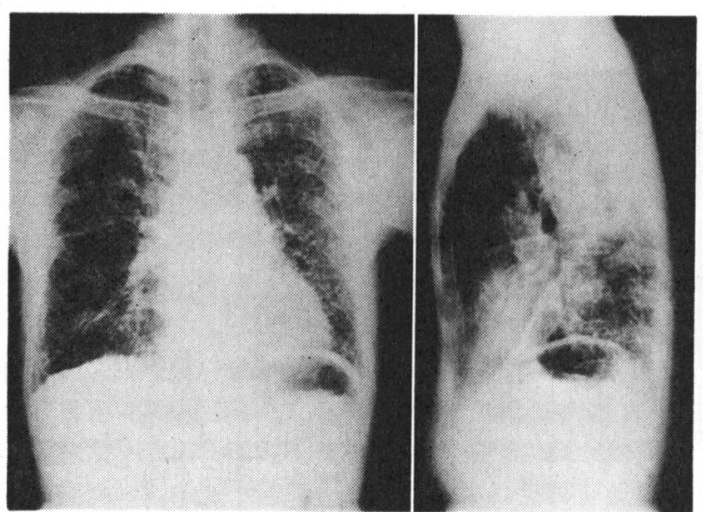

写真 2 胸部 X線像

全肺野のびまん性の線維性変化と一部に蜂巣状陰影 を認める

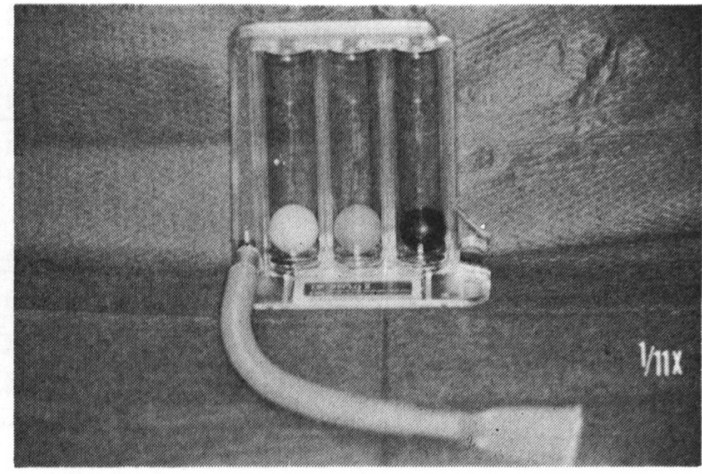

写真 3 トリフローII

深呼吸練習器で,ゆっくり大きく深呼吸することに より収縮した肺胞を拡張させる

表 2 術後経過（集中治療室にて 2 日間管理をした）

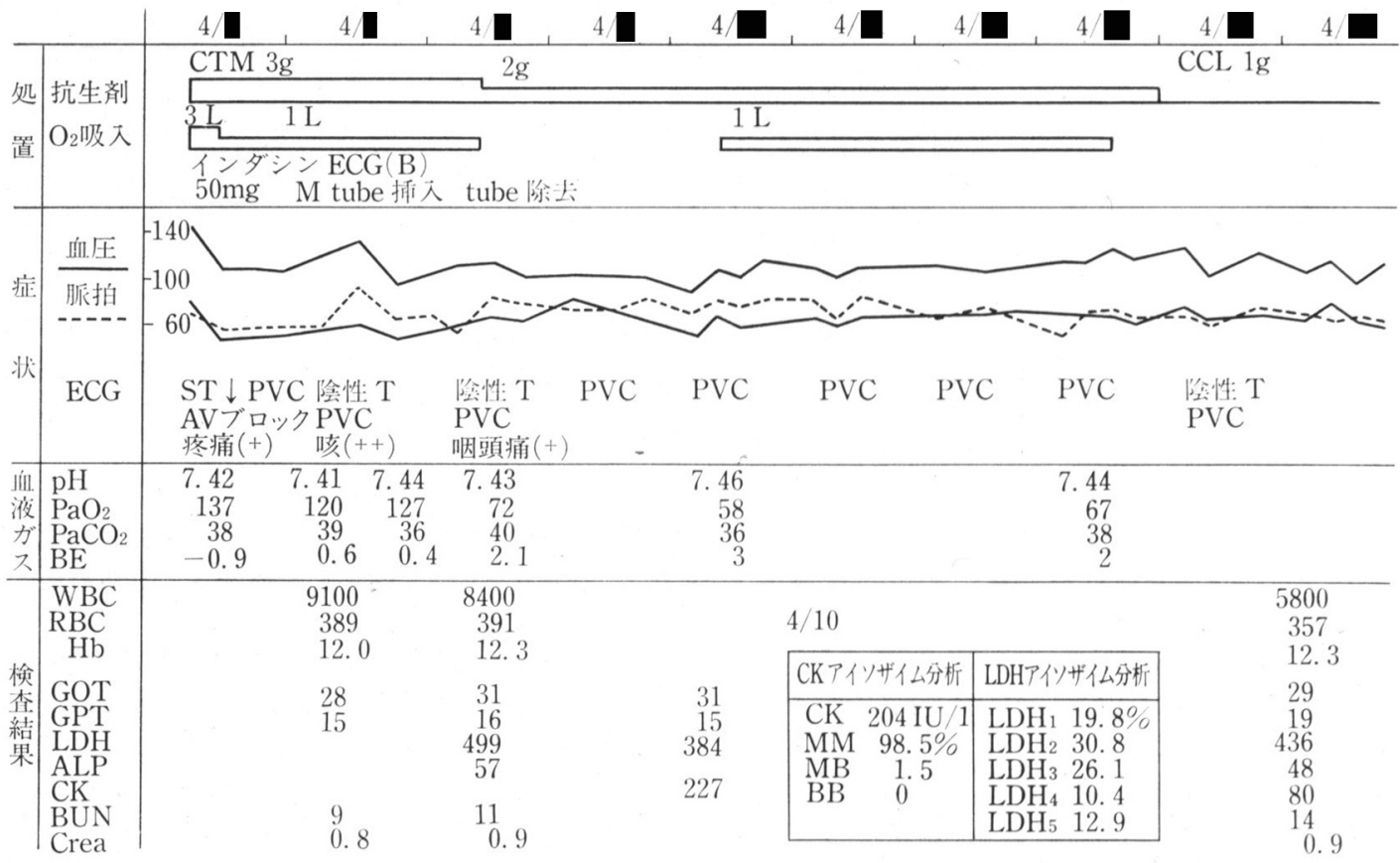

なく，完全左脚 プロックの基礎疾患は解明できなかっ た。

表 2 に術後より 10 日間の経過を示したが昭和 62 年 5 月 口日, 経過は良好にて退院した。

\section{考察}

心電図上の ST およびT波は電解質や薬剂の影響によ って子変化するが心筋障害や心笳虚血の判定に重要な情
報を提供している. しかし，完全左脚ブロックがある場 合は $\mathrm{ST}, \mathrm{T}$ 波の異常より心觔梗塞や心筋虚血, 心肥大 などを診断することは一般に不可能とされている。これ は心室内刺激伝導系の左脚が切断されると心室の興奮は まず中隔右室側から左室側に向い, ついで右室自由壁, 左室自由壁へと移る。したがって正常の中隔へクトルを 示す $\mathrm{V}_{1}$ のR波, $\mathrm{V}_{5}, \mathrm{~V}_{6}$ のq波はみられず, また心室 内脱分極異常のため再分極にも異常が生じ ST, T 波が 変化するためである1). 本症例の場合, 術後の心電図モ 
ニターで一過性の著明な ST の下降と,つづいて波の 逆転を単発性に認めたが，術後の身体的症状が改善する につれて陰転T波は正常化した。また，CK および LDH アイソザイム分析は正常ハターンを示したことから心筋 梗塞の合併は否定的となり，一過性の心筋虚血性変化と 推察された。

一過性の心筋虚血はいわゆる狭心症で，心㬳の代謝に 必要で十分量の血液の供給がなくなるために生ずる特有 な胸部不快感（狭心痛）を主症状とする臨床症候群であ る. 心㬳を虚血にする要因は 1 . 冠動脈血流量の減少,

2. 心竻の酸素需要量の増加，3. 動脈血の酸素分王の低 下であり，臨床的にはほとんどが冠動脈硬化の基盤の上 にいくつかの要因が重なって発生する2).

泰江 $5^{3)}$ は発生機序の観点から器質性狭心症と冠攣縮 性狭心症に分類している。それによると，器質性狭心症 は身体的労作や怒り，悲しみ，不安，警きなどの精神的 興奮によって生ずる心筋の酸素需要の增加に対して，冠 動脈の広汎かつ高度の器質的狭窄が存在するため供給が 追いつかなくなって発生する。発作は一定以上の労作で 必ず出現し，安静により消失するのが特徽である。一方，

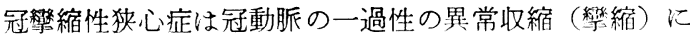
より心笳への酸素供給が急激に減少するために生ずる. 冠動脈の揫縮は冠動脈の緊張が元進している安静時, と くに夜間から早朝にかけての睡眠中あるいは起床時に起 こりやすい，また，安静時の副交感神経の活動が光進し ている状況下に交感神経が刺激されると冠動脈の孚杽縮が 容易に起こる．冠動脈の孚縮の誘因としては過呼吸なと のアルカローシス, 寒冷昇圧試験や運動負荷による交感 神経受容体の刺激，アルコール，副交感神経刺激薬物な 亡゙がある1).

狭心症の多くの場合は ST 上昇型であるが本症例のよ 5にST下降型もあり, Marzilli 5 5 , Yasue ら 上昇型のそれに比してより軽度で冠動脈の太い部分を 完全に閉塞しないか，またはびまん性であるか，冠動脈 の太い部分を完全に閉塞してもその末梢へ十分な側副血 行が発達しているか，冠動脈の比較的小さい枝が完全に 閉塞している場合であると述べている。

近年，麻酔中や麻酔覚醒後に一過性の心筋虚血を起こ した症例が多く報告され，全く予測できない場合もあり 注目されている7,8)。麻酔中に起きた冠動脈の攣縮は自

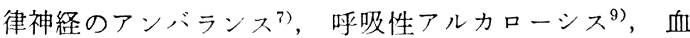
王低下 ${ }^{10)}$ ，体位変換 ${ }^{11)}$ な゙で報告され，柘酔覚醒後にお。

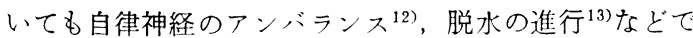
起きている。また，樋口ら ${ }^{14)}$ は腰椎麻酔直前に体位を変 換したところ一過性の心笳虑血を起こした症例を報告し ている，姿势変換に伴い動脈圧は一過性に変動すること が知られている。大住ら ${ }^{15)}$ は意識下において，体位を変 換すると開始早期に動脈王と心拍数が一過性に増加した と述べている，本症例では体位变換により㓌性 $\mathrm{T}$ 波が出
現した直後に心拍数や血王の测定はできなかったが，心 筋の酸絜需要の指摽として用いられる心拍数と収縮期血 压の皘 (double product) は6,000〜8,600で推移し，運 動時においても增加しなかった。

しかし, 術後の体位変换や咳嗽・去痰, 創部痛, 胃管 の刺激による鼻咽頭痛などがストレスとなり交感神経活 動を六進させ，冠動脈の攣縮を引き起こした可能性も考 えられる。立た，術後の抎張期血王の低下は冠動脈の血 流量を減少させ，さらに䟺血や肺機能障害が加わると動 脈血の酸素分圧は低下し，心筋を虚血にする誘因にもな ったと思われる。本症例は重篤な合併症もなく経過した が, 左室機能の低下した症例や狭心症発作の強度, 頻 度，持続時間が增加するのにつれて急死や急性心筋梗塞 に移行する危険性があるため注意を要する。

狭心症の発作には二トログリ七りンの舌下投与が奏効 し，持続性垔硝酸剂も有効である。発作の予防にはカル シウム拮抗剂がよく用いられ，冠動脈の擊維が起きやす いと判断された患者には術前よりカルシウム拮抗刜を投 与しておくことも勧められている ${ }^{16)}$

最近, 高秢者や重要臓器に合併症を伴った患者にも比 較的安全に手術は行われているが術中, 術後は循環器系 のみならず呼吸器系の管理にも十分な配虑が必要とされ る、高畧者になるにしたがい麻酔中の $\mathrm{PaO}_{2}$ が著明に低 下寸ること ${ }^{17)}$, 術後低酸素欰症や肺合併症の頻度が高く なるとの報告もある ${ }^{18)}$. 奥津ら ${ }^{19)}$ は胸部X線, 動脈血力 スその他の理学所見に何らの異常を認めないが，1秒率 の70\%以下または \% VC が $80 \%$ 以下を示す低肺機能者 の術後肺合併症は31. $2 \%$ に認め, 正常肺機能者の 2 倍以 上であったと報告している。本症例においては高粭であ ることに加えて, 術前より肺線維症, 肺二次感染があっ たため術後に致命的な肺合併症をきたさないよら細心の 注意を払った。すなわち, 術前より咳嗽・去疾や呼吸の 訓練, 手術時間の短縮, 出血量の抑制, 術後は酸素吸 入，ネブライザー，適切な鎮痛，抗生物質投与などによ り回避できたと考える。

頭頸部癌患者においても, 高耣者になるにしたがい全 身的合併症を䍜患していることが多い作田 ${ }^{20)}$ の頭頸 部癌患者の全身的合併症の分析では，全身疾患の治療を 継続中のものが $23 \%$, 腫瘍の治療上, 十分な配虑を必要 としたもので既往歴も含めると $50.6 \%$ に全身的合併症を 認めている，合併症のために手術を施行できなかったも の $3.5 \%$, 癌の一次治療にて全身的合併症の増悪をきた したものは約10\%であったと報告している。

今後とも, 高夦化と各種の全身的合併症の患者の増加 に対して，治療法の選択や患者管理に注意深い配麀とと もに絶えざる患者の観察が必要である。また，内科を始 めとした関連領域の専門医との連携が重要になると思わ れる. 
結

語

72歳の男性で著明な肺線維症, 肺二次感染に完全左脚 ブロックを伴った左側下顎歯肉癌患者において術後一過 性の心筋虚血性変化が疑われたが，重篤な肺合併症をき たすことなく軽快した 1 例を経験したのでその概要を報 告した.

稿を終えるにあたり，ご教示いただいた本学第 4 内科 学講座盛岡茂文助教授ならびに宮崎医科大学麻酔学講座 高崎真弓教授に深甚の謝意を表します。

本論文の要旨は第 2 回中国・四国齿科麻酔研究会（昭 和 62 年 7 月，広島）に拈いて発表した。

\section{引用文 献}

1) 河合忠一編集：心臓病学。第一版, 朝倉書店, 東京, 1986, 100頁.

2) 河合忠一編集：心臓病学。第一版, 朝倉書店, 東京, 1986, 731-732頁.

3）泰江弘文：狭心症と冠動胙の攀縮。病態生理 1: 807-813 1982.

4) 延吉正消：冠スパスム。臨床麻酔 7:1332-1336 1983.

5) Marzilli, M., L'Abbate, A., et al.. Coronary angiographic findings during angina at rest with ST depression. Circulation 56 Supple: III -831977.

6) Yasue, H., Omote, S., et al.: Comparison of coronary arteriographic findings during angina pectoris associated with S-T elevation or depression. Am J Cardiol 47: 539-546 1981.

7）小林裕子, 白鳥偷治, 他：全身麻酔中に ECG
上で一過性のST下降を呈した症例。臨床麻酔 10: 541-543 1986.

8）山野上敬夫, 向田圭子, 他：術中冠 ス 八 ス が強く㲛われた 3 症例。麻酔 35：1119-1125 1986.

9）渡㲽誠之, 百合野公庸，他：術中発生した冠 スパズム一症例。臨床と研究 63: 3973-3976 1986.

10）足立裕康, 坂昆光春, 他：全麻下，一過性 ST 上昇を示した 1 例。臨床麻酔 8:333-335 1984 .

11）野口純一, 小西睦美, 他：体位変换直後に起き た冠スパズムと思われる 1 症例. 臨床麻酔 10: 1093-1094 1986.

12）紊藤隆雄, 岡崎亀義, 他: 麻酔覚醒後発生した 一過性心筋虚血の治療経験。循環制御 2：1791891981.

13）広瀬和代, 竹原好文, 他: 抜管後, 一過性の ST-T 上昇をみた症例。臨床麻酔 6: 1011-1013 1982.

14）樋口昭子, 增田 明, 他：前投薬後, 腰椎麻酔 直前に冠動脈スバズムをきたした 1 例。麻酔 33: 1408-1412 1984.

15）大住寿俊，奥村福一郎，他：意識下と全身麻酔 下のヒトに扣ける体位変换時の動脈圧調節の差 異. 日本生理誌 47：237-242 1985.

16）海江田令次：麻酔と冠動脈スパズム。臨床麻酔 9: 1060-1068 1985.

17) 安本和正, 稲田豊：高龄者に対する術中呼吸 管理。麻酔 35：91-99 1986.

18）稲田 豊, 安本和正: 老人の街後肺合併症. 呼 吸と循環 26：753-759 1978.

19）奥津芳人，藤本啓子，他：肺機能障害患者の術 後肺合併症発生率に関する統計的考察。日胸 40: 649-655 1981.

20）作田正義, 墨 哲郎, 他：頭頸部癌患者にみら れた全身的合併症。 日口外誌 34: 51-55 1988. 